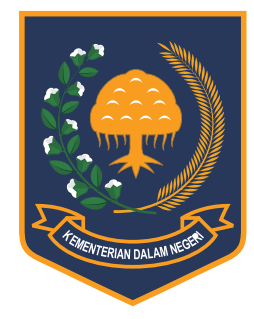

\title{
RESEARCH INNOVATION MODEL AT THE OFFICE OF RELIGIOUS RESEARCH AND DEVELOPMENT SEMARANG
}

\author{
Aji Sofanudin ${ }^{1}$, Andi Wahyudi ${ }^{2, *}$ \\ ${ }^{1}$ Office of Religious Research and Development Semarang \\ Jl. Untung Suropati Kav. 69-70 Bambankerep Ngaliyan Semarang 50182, Indonesia \\ ${ }^{2}$ Center for Public Administration Study and Government Official Training III \\ National Institute of Public Administration \\ Jl. HM. Ardans (Ring Road III) Samarinda 75124, Indonesia
}

Received: 10 November 2017; Accepted: 7 April 2018; Published online: 12 May 2018

DOI: $10.21787 /$ jbp.10.2018.101-110

\begin{abstract}
This research aimed to explore research innovation model in the Office of Religious Research and Development (RRD), Ministry of Religious Affairs (MORA) in Semarang. Research innovation model includes new ideas, practices, and methods in research field to further enhance the quality of research. The new ideas, practices, and methods consist of things that have been implemented, existed and practiced by the research institutions. This research used the qualitative approach and fact-finding method. The data were collected in several ways, such as experience and observation, interview, and secondary data. The result revealed the leader of the Office of RRD Semarang ideas concerning the importance of establishing quality-based policy research. In practice, those ideas were implemented in at least four forms of innovation which are the existences of (1) The Research's Internal Quality Guarantor Team, (2) Electronic Journals, (3) Collaborative Research and Development, (4) Policy Brief, and (5) MPEP Team. Those innovations were considered as a process and product innovation. Finally, it concluded that the leadership factor had a significant role in this organization to create such innovations.
\end{abstract}

Keywords: Innovation, Research Center, Leadership

\section{INTRODUCTION}

Recently there is a positive trend of innovation practices in the public sector. Several agencies put innovation as a strategic issue. For instance, LIPI (Indonesian Institute of Sciences) establish an Innovation Center, and NIPA (National Institute of Public Administration) also creates a new Deputy of Public Administration Innovation. Their tasks are to create and to endorse innovation practices in the public sector. The Ministry of Administrative Reform issues top innovations created by government agencies (Ministry of Administrative and Bureaucratic Reform, 2017) annually.

Numerous studies prove that innovation has created many changes in various organizations. Djalil (1999, p. ii) argues that "with the maximum cooperation effort between the madrasah principal, teachers and students, an innovation conducted by the madrasah principal was establish in the MIN (Madrasah Ibtidaiyah Negeri) Malang. Madrasah Ibtidaiyah Negeri is a Public Islamic School that has a similar level to elementary school 1. A case study of management of education innovation for quality oriented at Islamic Elementary School finds that some innovations emerged at MIN Malang, which are (1) learning innovation, (2) technology innovation, (3) curriculum innovation, (4) administration innovation, (5) structural innovation, (6) human resources innovation, (7) infrastructure innovation, and (8) social involving innovation (Sofanudin, 2016).

Anwar (2011) studied the process of educational renewing in Islamic boarding school,

\footnotetext{
* Corresponding Author

Phone : +6281347509208

Email : awahyudi2@yahoo.co.id
} 
the factors affect education renewal and also the implication of education renewal in Lirboyo Islamic Boarding School Kediri. Lirboyo boarding school was established in 1910 and had just conducted the education renewal in 1988 by opening Madrasah Tsanawiyah (MTs) (Madrasah Tsanawiyah is Islamic School that has similar level to junior high school) and Madrasah Aliyah (MA) HM Al-Mahrussiyah (Madrasah Aliyah is Islamic School that has similar level to senior high school). Then in 1995, Lirboyo boarding school opened schools as elementary school, junior high and senior high schools of Salafy Terpadu Ar-Risalah. Another innovation was by opening some boarding units beside the main boarding. This was done to avoid conflict between the offsprings of the founder.

Since innovation is a demanding matter for government agencies, the Ministry of Religious Affairs (MoRA) the Republic of Indonesia also puts innovation as one of its working culture values, including (1) Integrity, (2) Professionality, (3) Innovation, (4) Responsibility and (5) Role Model. Those values should be the organization spirit which is implemented by all employees. The Office of Religious Research and Development (RRD) or Balai Penelitian dan Pengembangan Agama Semarang is one of the central government agencies under the MoRA. Therefore, innovation becomes a value that must be embedded in this agency. The research activities at the Semarang Office of RRD at least consists of six stages, including (1) Establishing Term of Reference (TOR), (2) Designing the Operational (DO), (3) Creating Data Collection Instrument, (4) Data Collecting, (5) Data Analysis, and (6) Writing research report.

The main jobs of this office consist of research and development activities regarding religious affairs which includes the policy research, workshops and strengthening the research network.

Since the change of the head of the office of religious research and development in February 2014 , the office's performance is taken into account more at the national level. One of the evidence, for instance, is that even though the structural office level of RRD Semarang is equal to echelon III, but the head was trusted to be the keynote speaker for the activities involving echelon II, especially in journal writing and publishing.

The research results of the Office of RRD Semarang are also taken into account. The research publications are more intensive than before. This is all due to the work of all RRD's members. It is argued that the leadership factor is also important to consider especially related to the research quality.

Several improvements occur at the office after its recent leadership succession, for instance, researchers' publication in various scientific journals and newspaper. Some globally indexed journals have published their writings including IJIMS (International Journal Islam and Moslem Society), Harmoni, Penamas, and al-Qalam. While some the newspapers have published their popular articles including Suara Merdeka, Jawa Pos, Tribun, dan Wawasan. Some researchers are also recognized to be speakers on scientific forums both in internal and external forums. The MoRA as also invites the office's leader to present its researchers. Nowadays, the Office of RRD Semarang becomes a destination where university students in Central Java, such as Diponegoro University Semarang and IAIN Surakarta, conduct their apprentice and learning activities.

Several reviews show that leadership has a correlation to and affects innovation (Ancok, 2012; Djalil, 1999; Musyafak, 2015). Research innovation is important to enhance the research quality. Research innovation model is innovation variety in research management field. The leadership, therefore, is a critical factor to be considered to see his/her influence on organization's innovation.

The Office of RRD Semarang has unique characteristics because as a government agency this office has to obey government rules and support the ministry policies. On the other hand, as a research center, this agency must be independent and put concern on scientific ethics in conducting researches. The nature of the government bureaucracy is different from research spirit. Such situation also happens to other research centers under the ministries. Consequently, a question arises on the position of researchers at government agencies emerges, whether they are scientists or bureaucrats.

There are at least two challenges which Indonesian public sector faces in creating innovation. First, bureaucratic system and culture which emphasize on procedures and organizational hierarchy rather than organization performance. And second, the commitment of the leaders to encourage and also to protect their managers and staffs in creating innovation (Wahyudi, 2016). Leaders or decision-makers in the public-sector organizations should be smart and aware of these challenges.

Based on the explanation above, this research will examine the innovation varieties which have been introduced and implemented at the Office of RRD Semarang under Mr. Koeswinarno's leadership since February 2014. In addition, it is important to examine to what extent the role of leadership affects innovation in the organization.

\section{Method}

This research used a qualitative method aimed to comprehend the phenomena experienced by research subjects, such as behavior, perception, 
motivation, and action. The experiences were expressed holistically and described in words in a particular and natural context by utilizing various natural methods (Moleong, 2006, p. 6).

Data was collected in several ways. First, they were collected from the natural setting as a direct data resource. Naturalistic paradigm was applied to enable the researcher to find meaning from each phenomenon, thus local wisdom, traditional wisdom, and also moral values would be found, as well as the theories of the researched subjects. Finding meaning to these data could only be done if the depth of facts gained is achieved. Second, interviewed the chairman of the Office of RRD Semarang as the key source. The interview was intended to gain information on innovative ideas and the underlying reason. Finally, secondary data were collected and used to enrich information on innovation theories, issues, and practices in various organizations.

The collected data were selected, clarified, and clustered based on the type of innovation practices. Triangulation method was used to confirm the data that were gained from the interview, observation, and secondary data, such as official document and presentation material. Based on the collected data this study expected to find out and to describe the research innovation model at the Office of RRD Semarang. This study used a fact-finding method - a term introduced by Mas'ud (2013) to analyze the collected data. By this method, researchers promptly portray the phenomena and find out the facts that happened in the field (research's subject and object).

\section{RESULTS AND DISCUSSION}

\section{A. Innovations at RRD Semarang}

Research Innovation Model is a new breakthrough which has been implemented by the Office of RRD Semarang which is different from previous one in the setting of increasing the quality of research results. Figure 1 shows a framework of research innovation model at the Office of RRD Semarang. According to Koeswinarno (personal communication, August 15, 2016), the head of RRD Semarang Office:

"The main problem of research is the inadequate resource and the research results themselves. However, I do not want to straightly "hit" the human resource. I prefer to do other things such as increasing journals, enhancing research procedure, and so on but in the end, those will end up there. The keyword for quality is its usability/applicability and publication. Ideally, a public test should be conducted to research's

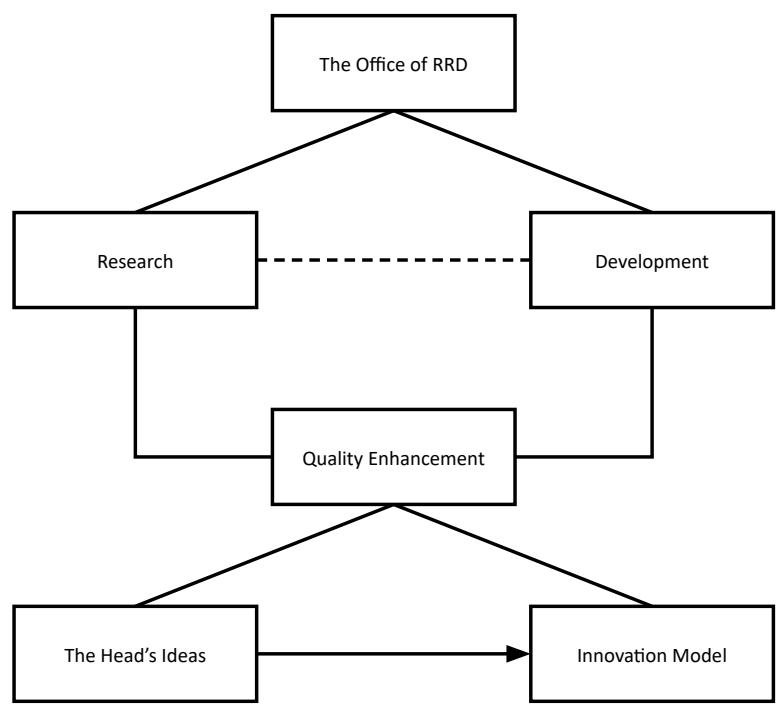

Figure 1. Framework of Innovation Model at RRD Semarang

results, so that they are more measurable."

The statement is in accordance to the changing project document created during his Leadership Education and Training Level III August 2014 period, batch XLII, The Ministry of Religious Affair of Republic Indonesia in cooperation with National Institute of Public Administration. That document is the Report of the Reformation Project Implementation entitled: "Building Quality based Policy Research in Religion Research and Development Center of Semarang".

Based on the fact-finding, several forms of innovation have been started in the Office of RRD Semarang since 2014, included TPMIP (Tim Pengendali Mutu Internal Penelitian), electronic journal, collaborative research and development, policy brief, and MPEP (Majelis Pertimbangan Etik Peneliti). They are considered as innovations in the Office of RRD Semarang because they are new breakthroughs that applied in the office.

\section{1) TPMIP Innovation}

TPMIP stands for Tim Pengendali Mutu Internal Penelitian or Internal Research Quality Assurance Team. TPMIP is an internal unit of RRD Semarang responsible for ensuring the research quality, a kind of quality control unit. TPMIP was formed and assigned by the principal of RRD Semarang with a tenure of 3 years.

TPMIP has two duties. First, to control the quality of research results and scientific writings which will be published. And the second, to assess performance and scientific writings of each researcher in terms of proposing their credit point. Therefore, TPMIP is also working as TP2U or the Unit Researcher's Assessor Team. 

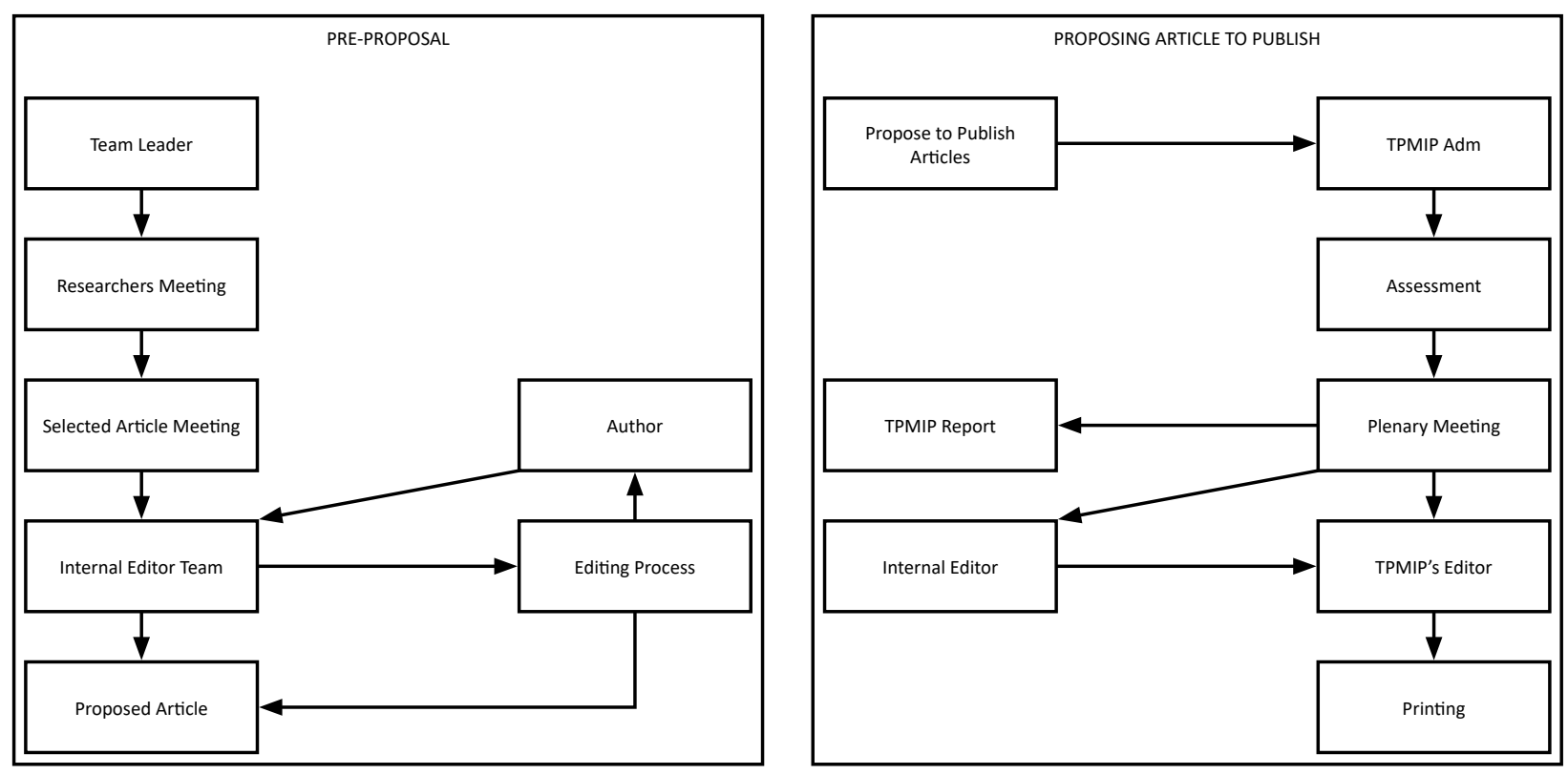

Figure 2. TPMIP Work Flow

All the research to be published either in form of collection or proceeding was evaluated by TPIMP. TPMIP created a format to be followed by all researchers in writing books or proceedings. Because of its duties, TPIMP is considered as a "super body" unit. It has an authority to control the research quality and manuscripts that will be submitted to any journal. The unit also assesses the researchers' proposal of credit points. Figure 3 shows that TPMIP has a strong role in the prepublication process and its recommendation will determine whether or not an article is appropriate to be published.

In the assessment, TPIMP was guided by two aspects, (1) presentation (30\%) and (2) substance (70\%). The presentation aspect included the style

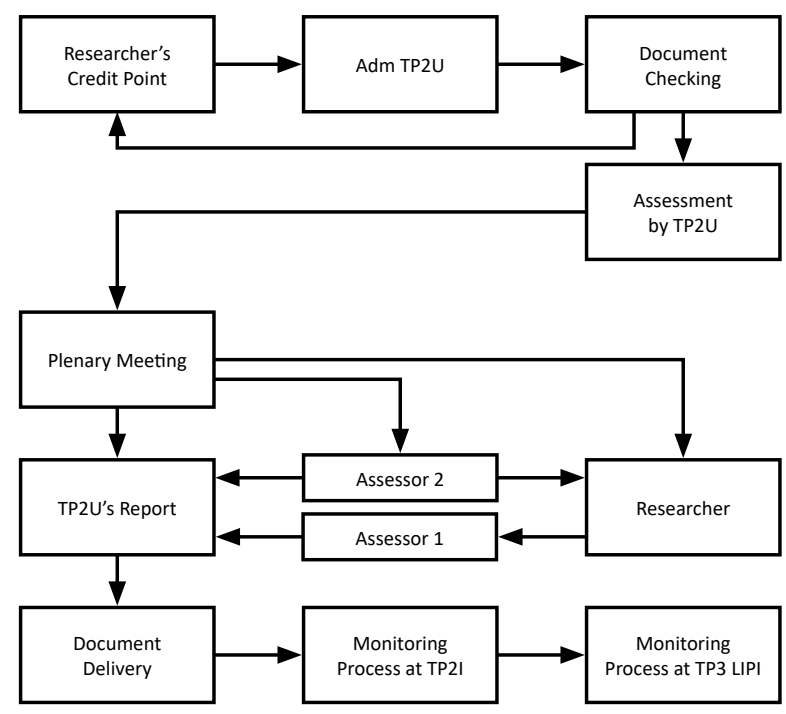

Figure 3. TP2U Work Flow of language, originality, and organization. While the substance aspect included the background, result finding and discussion, conclusion, and reference. In addition, TPIMP was also acting as TP2U, the unit research assessor team, it assessed the researcher's performance to propose the researcher's credit score. The TP2U's workflow is as follows.

There were three projects mentioned in the report of reformation project implementation titled "Building Quality based Policy Research in Religion Research and Development Center of Semarang", which were: (1) Internal Team of Research Quality Assurance, (2) New SOP (Standard Operating Procedure) of Team Creation and (3) Book Writing Guidance Team (Koeswinarno, 2014: 8). However, two things mentioned last is the "heritage" of the previous head.

The TPMIP Model implemented at the Office of RRD Semarang was then adopted by the Research and Development and Training Agency, the Ministry of Religious Affairs. All research agencies under the Ministry of Religious Affairs were recently instructed to create such unit named TPMPP (Tim Penjamin Mutu Penelitian dan Pengembangan) or Quality Assurance Team for Research and Development.

The TPMPP's members are senior researchers and representatives from each research division including religious public fostering, religious education, and religious khazanah divisions. The team's jobs are to assure the quality of research and development.

\section{2) Electronic Journal}

Electronic or online journal innovation is a breakthrough by launching an electronic journal 
or e-journal to publish research results with an ISSN (International Standard Serial Number). The electronic journal was also a media to convey information and communication. The e-journal provides the tool to enrich the value of a conventional journal (publication and in-depth review) enabling it to answer the globalization challenge.

The e-journal did not substitute its conventional journal, the Jurnal Analisa, it strengthened the conventional journal through writer's management, scientific writing, and feedback, to the extent of discussing freely it without boundary. The Jurnal Analisa itself has been published twice a year since 1996. And since 2016, its English version was available. This journal involves a large number of reviewers from various countries and is indexed by various indexers, such as Google Scholar, DOAJ, Crossref, Open Academic Journal Index (OAJI), Indonesian Publication Index (IPI), and Indonesian Scientific Journal Database (ISJD) PDII LIPI.

In the scope of Research and Development Institution and The MoRA's Education and Training Institution, the existence of Jurnal Analisa was considered as the pioneer in applying e-journal system. On June 8, 2016, an e-journal technical guidance was held, where the journal management in Research and Development Institution and The MoRA's Education and Training institution and the management of journal in RRD Semarang participated. The management of Jurnal Analisa became the keynote speakers at that event.

The journal management also invited (being the keynote speakers) to share their experience in the research and development centers in the environment of Research and Development Institution and The MoRA's education and training institution. The management of Jurnal Analisa was considered successful in making this journal on the path to be an international journal.

\section{3) Collaborative Research and Development}

The main activities in the Office of RRD Semarang consist of two matters, which are research and development. Collaborative research and development have at least two definitions. First, the combination of research and development activities where development should be based on research, it has to produce particular model or product. Development activity in the form of workshop meeting is the "continuation" of the research process. Second, research with a collaborative nature. Before the collaboration mechanism was implemented, the research activities at the RRD Semarang Office were conducted by three research fields separately, and they usually have their own research topics. Based on the MoRA Decree No. 346 of 2004, the research and development activities consist of three fields, namely (1) the religious life, (2) the religion and religious education, and (3) the religious lecture/khazanah fields. By collaborative research, all researchers in those three fields had one similar research topic.

Hence, the "intellectuality" and "bravery" to do new things are needed. It was not easy to integrate different point of views about the importance of this collaborative research. Mr. Koeswinarno had the strength in this matter being a professor and having work experience in the central office, thus he knows the "saturated" research topics. For example, the collaborative research that has been conducted is about "radicalism" and "survey of satisfaction index".

Researchers in those three fields conduct a discussion upon a particular issue. On the radicalism topic, all researchers at the Office of RRD Semarang reviewed the topic from their perspectives, such as radicalism from the lecture, radicalism from educational aspect and radicalism in social life. The discussed topics were including the satisfaction index of KUA (Religious Affair Administration Office), Hajj pilgrimage, and teachers. The research model was designed as such that in conducting the site research the researchers had to do it collaboratively in a team.

The effect emerged from this innovation was a more focused research. Reference and literature review were better, and the range of research was wider. Other implications arose from this is that there was a more intensive discussion in the preresearch stage, in the research process itself and also post research between the researchers.

The research activities in the Office of Religious Research and Development Center of Semarang consist of: (1) Creating Term of Reference (TOR), (2) Establishing Operational Design (OD), (3) Establishing Data Collection Instrument, (4) Data Collection/ Field, (5) Data Analysis, and (6) Writing the research report. Each stage had to be done with responsibility.

To enhance the research quality, this research center created a discussion forum, namely RDK (Rapat Dalam Kantor) or in-office meeting. This discussion forum was a knowledge sharing forum for researchers that was held out of business hours. For their attendance, researchers gain additional benefits. RDK could be held in the preliminary stage of research, in the process or post research. Thus, in each stage, there were a strengthening of theory, methodology, results and research analysis aspects.

The RDK was a discussion in the office with or without an invited speaker because all participants were the speakers. Besides an academic strengthening activity, RDK activity also increased the welfare of the researchers- each researcher 
involved received a transportation allowance because it was held outside office hour.

The collaborative research model will be adopted by Research Center of Religion Education and Religious Affairs in the central office. In 2018, a national research on "Index of Religious Education and Religious Affairs" will be conducted and it will involve all research units in the ministry to do the certain related topic. This collaborative research is endorsed in order to build multi-disciplines research that involves various disciplines and perspectives. In other words, collaborative research at the Office of RRD Semarang is a form of multi-discipline research which involves various disciplines.

\section{4) Policy Brief}

Frequently the researchers forgot to "pack" their research results properly. Even though the research results are good and valuable but if they are not well packaged, they will be only piled up in the library or warehouse.

The packaging model which had been conducted was by publishing them as books. The published books look like a professional publisher's books. The main issue was to make these research "marketable" where the content and display were not inferior to the other books in the market.

Another packaging was the internal one, where it was not possible to read the research in its "entirety" format. Therefore, an executive summary (usually 2-5 pages) of the essence of the research was made in a policy brief model, in the form of a bulletin containing the policy alternatives recommendation.

This policy brief model was created to introduce the research results to the competent parties. With this model, it would be easier for the decision makers to digest the results of the research because it is concise.

Policy brief format was created because it was recognized that the research results of the Office of RRD Semarang have more policy research nuance. The policy brief was indirectly aimed at the potential parties using the results of the Office of RRD Semarang, either executive, legislative or judicative. With the policy brief format, it was also easier for mass media to pack the results in the form of news. It was also more important for the decision maker and stakeholder to know promptly of what was published by the Office of RRD Semarang.

\section{5) $M P E P$}

One of the innovation models at the Office of RRD Semarang was MPEP responsible for the scrutiny of ethical issues of researchers and research activities. MPEP (Majelis Pertimbangan Etik Peneliti) or Chamber of Researcher Ethics.
The chamber was supposed to be a guard unit that scrutiny if the research activity is ethically on the right track. So far, the chamber had conducted meetings to identify and investigate some problems related to unethical behaviors of researchers. The chamber then recommended punishments for suspected researches to the office manager.

Another acknowledgment toward the Office of RRD Semarang was the increased demand for research report from some stakeholders. In assessing an innovation in the public sector, it needs to identify who are the users of the organization's product or service. As one of the public institutions, the Office of RRD Semarang needs to put concern about it. Some stakeholders of the Office of RRD Semarang were the MoRA Office of East Java Regional, State Islamic University of Walisongo, High School in Central Java, State Intelligence Agency (BIN), and Indonesia Science Institute (LIPI). They invited and sometimes met the RRD's researchers to discuss any issue related to religious and Islamic matters. In addition, the Office of RRD Semarang was appointed by MORA Central Office as the pilot project of Integrity Zone 2017. In 2017, the office implemented the work system based on integrity zone.

Some authors might have a different definition of innovation. However, innovation basically should contain a novelty. Innovation has various forms and some authors classify them in numerous types from simple to complex classification (Hartley, 2005; Miller \& Miller, 2012; Walker, 2006). Walker (2006) simply classifies innovation models into three types, such as product, process, and ancillary innovations. Then Hartley (2005) classifies types of innovation in larger numbers. Innovation, according to Hartley (2005) can be created at least in seven forms, such as product innovation, service innovation, process innovation, position innovation, strategic innovation, governance innovation, and rhetorical innovation.

It is argued that according to Walker's typology (2006), various breakthroughs implemented at the Office of RRD Semarang can be classified into two types. First, process innovation occurred in managing research activities in this research center. This innovation included the establishment of TPMIP or Internal Research Quality Assurance Team and the Collaborative Research and Development.

The operationalization of TPMIP directly affected research process in this organization, because there was a quality control mechanism toward research and article publication that did not exist before. Then the establishment of the Collaborative Research and Development allowed researchers to build networking among researcher communities not only in the internal organization 
but also in the external one. This networking enabled researchers to enrich their knowledge and experience and expected to improve the research quality.

And second, product innovation occurred when this organization produced e-journal and policy brief. Although e-journal and policy brief are not new things in the nature of policy research, in the context of the Office of Religion Research and Development Semarang they are new products. Therefore, the novelty of this practice is that contextually those breakthroughs did not exist before.

\section{B. Leadership and Improvement}

Yapp (2005) argues that leadership is a key element to support innovation works in an organization. It directs members in terms of where the organization is going and how to get there. Good leadership will assist organization members in conducting innovation process development, includes supporting imagination and concept creation, clarifying direction, and designing and developing the process to achieve goals.

Leadership was a prominent factor in creating breakthroughs at the Office of RRD Semarang. The role of new leader in assisting and guiding his members (researchers) has significant value to endorse researchers moving forward. Not only endorsing members, the role of new leader also emerges in creating ideas and implement it. This is innovation, implementing ideas into reality. According to Ancok (2012, p. 35) that innovation is a process of thinking and implementing that idea.

Why does it work? There were some leader's characteristics that influence the practice of innovation at the Office of RRD Semarang. First of all was the leader's qualification and competence. The leader has a formal qualification as a senior researcher which is called Peneliti Utama and a professor. His profession as senior researcher enabled him to understand research world and to supports his job to operate a research center.

Second, an individual characteristic that was easy to interact with all levels of member both in formal and informal meetings. This attitude creates a "low-power distance" between the leader and his members. The term of power distance was introduced by Hofstede to describe the relationship between leader and his members in an organization. The informal communication was often made to share any information and to absorb any idea or complaint from members. This communication way allowed the members to feel free to express their ideas and opinion to build a better organization.

This unique practice of communication was conducted when they were involved in a conversation at the Gazebo or weekly coffee morning on Fridays.
While they were having a meal and coffee in the office, or sometimes in the parking area.

Third, the commitment to improve the research quality was frequently delivered at the various occasion. This commitment supported the organization in achieving the vision.

Fourth, gradual steps to create changes in order to minimize any possible resistance from the members. Building a harmony among members, both researchers, and staffs, intended to improve the organization performance. In fact, there was a gap between members, some members were on pro status quo side, while other members were on the pro-change side. But those opposite members were then united by rearranging their table positions in the office. This effort was intended to eliminate division among researchers.

Segregation between researchers and nonresearcher staffs was one other problem. Researcher and staff had a different job description that created the gap between them. To solve this problem, they were involved in some activities that allowed them to work together, for instance in books procurement process, rearrangement of the layout the room, and staffs were even involved in collecting data.

Fifth, members' involvement in planning activities in the office. Employees were engaged more intensively to arrange work programs. This created transparency in the office.

Project monitoring that was conducted by secretariat unit was recently changed. The monitoring activity was conducted together by secretariat unit and senior researchers as part of supervision job. This supervision was intended to control the research process and quality, including to confirm that the required data in research were well collected.

Those efforts enabled innovation at the Office of RRD Semarang to succeed. It was argued that this leadership style allowed a better trust of the leader or manager. However, some critiques emerged on this leadership style. For example, the frequency of religious activities in the office decreased as many researchers and staffs focused more on the field data collecting tasks. In Ramadhan month many researchers sometimes were still collecting data. Whereas it never happened before. This caused complaint from members.

To ensure that the innovations are sustained in an organization when the leader has changed, it needs to create an innovation culture in the office. Innovation culture allows innovation to be institutionalized as organization culture (Utomo, 2016 , p. 148). When innovation becomes the organizational culture, then its sustainability can be maintained when the leader changes. 
In the context of the Office of RRD Semarang, innovation culture should be embedded in the organization culture. Otherwise, innovation in this office would stop when the leader moves to another unit. As a government research office under ministry's control, it is easy for the unit leader to be promoted or move out from the current organization. Furthermore, the government is planning to create a new regulation in which a researcher cannot serve as a public manager. Therefore, he must decide to choose to be a researcher or a manager.

It was argued that individual cultural background of the leader also suitable for this research office. During his leadership, Koeswinarno was influenced by Javanese philosophy of "alon-alon waton kelakon". That gradual steps were needed to make a change or to complete a task. The process might be slower but effective. Therefore, there was no sudden change drastically in short time.

It might be an application of al-Muhafadzatu alal Qadimis Shalih wal ahdu bi al-Jadidil Ashlah, to preserve old good tradition and to create a better new tradition. For example, to increase discipline among researchers and staffs in the office, a weekly briefing was still being conducted. However, the briefing leader was not chief of the office or lower manager anymore. The senior researcher was appointed to lead the briefing.

To strengthen harmony among staffs, some other activities were organized. Weekly exercises and a coffee morning were usually held on Friday. While on other time, a lunch together was held occasionally. It was argued that those activities were efforts to tackle challenges in creating innovation in the Office of RRD Semarang.

\section{1) Constraints}

Innovation might come from creative ideas among people in the organization or from other organizations. In general, several challenges in implementing innovative ideas often comes from inside the organization, such as conflict of interest, different priority in the organization, and limited resources (Wahyudi, 2009, p. 365).

In conducting research collaboration, there were some pitfalls that the Office of RRD Semarang faces. First, schedule problem emerged because the research involved several researchers from different divisions. The divisions usually had their own activities; therefore, the research team should arrange the best schedule that met all researchers' schedule. This problem was a consequent of the various responsibilities that are common for government researchers in Indonesia (Koeswinarno, personal communication, August 17, 2017).

Second, the duration of collecting field data that took a long time. It potentially influenced the schedule of other activities of the researchers.
Therefore, a schedule synchronizing was needed. In conducting quantitative research, the Office of RRD Semarang supposedly uses 10-10 duration model of collecting data. It meant that there were two field visits. The first 10 days was to collect data, and then the second 10 days was to verify and complete the data. The researchers also spared three additional days to perform validity and reliability tests (Koeswinarno, personal communication, August 17, 2017).

On the other hand, based on author's experience and observation, in conducting qualitative research, the Office of RRD Semarang used 7-18 duration model. The first seven days were pre-research and the second 18 days were for data collection. The preresearch was supposed to collect initial information related to research issue. While the second 18 days were supposed to gain and collect data deeply and should focus on the research topic. This duration model was intended to solve the technical problem of research schedule among researchers that with various divisions.

Third, based on author's experience and observation, to decide a research topic is a problematic issue in conducting research collaboration. Since the researchers have various opinions and background, they have different perspectives and arguments on an issue. It is not easy to make a decision about what topic or title that accommodate all researchers.

A strong leadership is needed to manage such discussion. In 2016 and 2017, long discussions of radicalism issue were conducted, and they involved researchers from all divisions. In 2016, the discussion emphasized on radicalism in religious civil groups or communities called as a Mass Organization (Ormas). Then in 2017, the discussion emphasized radicalism in education institutions, such as school and campus.

And finally, the change of researchers' attitude because of research procedure. The change of research procedure requires changes of mindset, attitude, and behavior of the researchers.

Monitoring and evaluation that was emphasized on administrative aspects were changed to a substantive aspect. The change consequently influenced to human resource aspect, for instance, the Office of RRD Semarang hired a research supervisor as a new position. However, a critique emerges in Koeswinarno's leadership was that during his leadership, the office experienced a lack of religious values. During previous Ramadhan month, religious activities were conducted in the office, such as Tarawih and witir together.

Furthermore, during Idul Adha celebration researchers and staffs also performed charity activities for society. Such activities were also done in delivering zakat or infaq for society during Idul 
Fitri celebration. The activities were volunteered by staffs but not a formal policy.

\section{2) Value for Stakeholder}

Research provides values for people if they get benefits or advantages from the research activity. Therefore, researchers need to publish their research through various dissemination channels to enable the people to access the research result. If people or stakeholders get advantages from the work of the Office of RRD Semarang, then this research center creates value for the people. Moore (1995) calls such value as public value.

The value that is made by the research center can be assessed based on to what extent the research is cited by other scientists or authors. Hashimoto, Kajikawa, Sakata, Takeda, \& Matsushima (2012) argue that innovation research is analyzed by citation network analysis which consists of three clusters, technological innovation, fundamental innovation, and management innovation.

So far, the Jurnal Analisis which was published by the Office of RRD Semarang contributed more than 400 articles since its first edition in 1996. But its online version was just launched in 2016, therefore, it was not easy to trace the number of citations before an online version was launched. Some people might cite the articles for some purposes and they did not publish them online, such as for thesis or some report. The publisher did not have any record of the number of citations of the printed version.

On the otherhand, the onlineversion is traceable. Based on Google Scholar data on https://scholar. google.co.id/citations?user=qtd_6JcAAAAJ\&hl=en, Jurnal Analisis gets 20 citations. And since its online version was launched, Jurnal Analisa had at least 75 indexes. The achievements mean that this journal is recognized as one of the reputable scientific journals.

\section{ConClusion}

Research innovation is the innovation in research field or innovation to increase the research quality. Research innovation is an idea, object, method which are viewed or observed as new to a person or a group of people (society), either in form of invention result (new finding) or discovery (first found), which is used to gain objective or to solve the problem faced.

Research Innovation Model implemented by the Religion Research and Development Center of Semarang is different from the previous one in the term of increasing the research quality. Research Innovation Model is the new resources management process (idea, practice, object, method) in research field to increase the research quality.

In Semarang's Religion Research and Development Center, there are several research innovation models found, they are (1) Internal Team of Research Quality Assurance, (2) Electronic Journal, (3) Collaborative Research and Development, (4) Executive Summary, and (5) Chamber of Researcher Ethics. They might not new things in other organizations, but in the context of the Office of RRD Semarang, they have the element of novelty. And the keyword of innovation is a novelty. Finally, leadership factor is the factor that has the most influence on innovation at the Office of RRD Semarang. Numerous innovations at RDD Semarang shows the extent of leadership's influence in generating innovative activities. The friendly leadership is accessible to officials. Informal and cultural approaches in leading the office also make officials feel free to express their innovative ideas. This kind of leadership affects innovation development in the office.

The idea of the Head of the RRD on "Building Quality based Research Model Policy" should be implemented continuously. The aspects which have not been implemented should be followed up. The innovation sustainability should be maintained to keep this research center going in the future.

A quality research is a central point for the objective and achievement of this research office. A quality research will not exist without a quality research process. A quality research process will not exist without a great organization. There will be no great organization without a great leader. The strong commitment from all the family of the Office of RRD Semarang is the supporting pillar for everything else.

\section{ACKNOWLEDGEMENT}

We would like to thank the head of the Office of RRD Semarang who gave us the opportunity to conduct this study. Secondly, thanks also go to the head of the TPMIP Team, Jurnal Analisa Team, and all members the Office of RRD Semarang for their data support. Thirdly, we also thank Prof. Dr. Fathur Rokhman, M.Hum., Prof. Dr. Wasino, M.Hum., and Prof. Dr. Rusdarti, M.Si. for their guidance in conducting this research. In addition, we also thank anonymous reviewers for their comments on this paper.

\section{REFERENCES}

Ancok, D. (2012). Psikologi Kepemimpinan \& Inovasi. Jakarta: Erlangga.

Anwar, A. (2011). Pembaruan Pendidikan di Pesantren Lirboyo Kediri (2nd ed.). Yogyakarta: Pustaka Pelajar.

Djalil, A. (1999). Kepemimpinan dan Inovasi Pendidikan Islam (Studi Kasus pada Madrasah Ibtidaiyah Negeri Malang 1). Muhammadiyah University of Malang. 
Hartley, J. (2005). Innovation in Governance and Public Services: Past and Present. Public Money and Management, 25(1), 27-34. http://doi. org/10.1111/j.1467-9302.2005.00447.x

Hashimoto, M., Kajikawa, Y., Sakata, I., Takeda, Y., \& Matsushima, K. (2012). Academic Landscape of Innovation Research and National Innovation System Policy Reformation in Japan and the United States. International Journal of Innovation and Technology Management, 9(6), 1250044. http://doi.org/10.1142/ S0219877012500447

Mas'ud, A. R. (2013). Politics of the Nation and Madrasah's Policy. Edukasi, 11(3), 277-288. Retrieved from http://jurnaledukasikemenag. org/index.php/edukasi/article/view/414

Miller, L., \& Miller, R. (2012). Classifying Innovation. International Journal of Innovation and Technology Management, 9(1), 1250004. http://doi.org/10.1142/S0219877012500046

Ministry of Administrative and Bureaucratic Reform. (2017, April 18). Kementerian Pendayagunaan Aparatur Negara dan Reformasi Birokrasi Kementerian PANRB Tetapkan Top 99 Inovasi Pelayanan Publik 2017. Retrieved August 24, 2018, from https://www.menpan.go.id/site/ berita-terkini/kementerian-panrb-tetapkantop-99-inovasi-pelayanan-publik-2017

Moleong, L. J. (2006). Metodologi Penelitian Kualitatif. Bandung: Remaja Rosdakarya.

Moore, M. H. (1995). Creating Public Value: Strategic
Management in Government. Cambridge, MA: Harvard University Press.

Musyafak, N. (2015). Kepemimpinan Kyai dan Sikap Santri terhadap Inovasi Pertanian di Pondok Pesantren Al Hikmah 2 Benda Sirampog Brebes Jawa Tengah. Gadjah Mada University.

Sofanudin, A. (2016). Manajemen Inovasi Pendidikan Berorientasi Mutu pada MIN Malang 1 Kota Malang. Penamas (Jurnal Penelitian Keagamaan Dan Kemasyarakatan), 29(1), 81-94. Retrieved from http://blajakarta.kemenag.go.id/ journal/index.php/penamas/article/view/22

Utomo, T. W. W. (2016). Inovasi Harga Mati: Sebuah Pengantar Inovasi Administrasi Negara. Jakarta: Rajawali Pers.

Wahyudi, A. (2009). Inovasi dan Kreativitas. In A. Sirodz (Ed.), Dari Budaya Kerja Menuju Kinerja Organisasi. Samarinda: PKP2A III LAN.

Wahyudi, A. (2016). Value-added in Public Service Innovation: The Practice at Integrated Service Units in Pontianak Municipality and Tanah Bumbu District. Jurnal Bina Praja, 8(1), 49-58. http://doi.org/10.21787/JBP.08.2016.49-58

Walker, R. M. (2006). Innovation Type and Diffusion: An Empirical Analysis of Local Government. Public Administration, 84(2), 311-335. http:// doi.org/10.1111/j.1467-9299.2006.00004.x

Yapp, C. (2005). Innovation, futures thinking and leadership. Public Money and Management, 25(1), 57-60. http://doi.org/10.1111/j.14679302.2005.00451.x 